\title{
David Wästerfors
}

University of Lund, Sweden

\section{Analyzing Social Ties in Total Institutions}

DOI: https://doi.org/10.18778/1733-8077.8.2.02

Abstract A common view is that an individual delinquent can be rehabilitated in a "home" in the countryside, away from his or her original urban social ties. An ironic result is new social ties with other juvenile delinquents as they spend a considerable amount of time together at a secluded institution. Drawing on ethnographic studies in residential care institutions, this article discusses two aspects to consider when analyzing social ties in such settings: the institutional prerequisites for and the everyday achievement of isolation and intimacy.

Keywords Isolation; Intimacy; Social Ties; Residential Youth Care; Total Institutions

\begin{abstract}
David Wästerfors is an Associate ProDavid Wästerfors is an Associate Professor and Associate Senior Lecturer in the Department of Sociology at Lund University. His interests include criminology, social psychology, ethnography and interactionism.

$:$ email address: david.wasterfors@soc.lu.se

$\mathrm{T}$ here are at least two reasons to study social in residential youth care. First, there is an irony in placing "troublesome" youth in residential care for rehabilitation, providing excellent conditions for socialization with other youngsters having the same or similar problems. Studies in social work are concerned about "peer influence" (Andreassen 2003:137-142; Dodge,
\end{abstract}

Dishion and Lansford 2006) - that is to say, processes through which fellow inmates transform each other in morally unwanted ways - and research reviews conclude by suggesting shorter and more well-organized visits at institutions (Andreassen 2003:137-142; Dodge et al. 2006). The debate may seem new, but it is in fact quite traditional. As Foucault (1998) shows, criticism of the prison or prison-like institution for reinforcing the problem it was supposed to solve is as old as the prison itself. In the more specific case of youth care, Polsky (1962) has reported the existence and risks of a "deviant subculture" and its pecking orders among troublesome boys. Bondeson (1974) has shown that criminal attitudes are strengthened during imprisonment, and Levin (1998) found a local youth culture within an institution that obstructed treatment. Still, there seem to be few alternatives to contemporary society's general and intense use of incarceration as a response to crime (Christie 2004; Wacquant 2009). Social ties offer a more analytical and less normative way to conceptualize both what residential treatment tries to achieve - cutting off troublesome youth from previous contacts and memberships - and what its critics fear might be its consequence: getting them even more deeply involved in "wrong" social circles or differential associations (Sutherland and Cressey 1970).

Second, studies of social ties in residential youth care may help us conceptualize complex layers of durable interaction patterns in and around total institutions in general, as well as actors' various uses of them. For followers of Erving Goffman's (1990a) classic study, it comes as no surprise that institutions for troublesome youth have much in common with other institutions in which inmates spend long stretches of time in close company with each other and with staff, as at "homes" for the elderly, for example. In Gubrium's (1997) ethnographic study of an American nursing home, Living and Dying at Murray Manor, the elderly displayed agony over the broken social ties created by their institutionalization, but they also found ways to maintain some of those ties, as well as to establish new ones. The importance of telephone calls to friends and relatives "outside" and the many and careful preparations for excursions "back home" that Gubrium reports are recurrent in youth care as well, as are inmates' ways of forming cliques, supporting relationships, and creating friendships within the institution. Studies of social ties in residential youth care will be fruitful for elaborating transferable sociological perspectives on life in total institutions, especially regarding how inmates, as competent and reflexive agents (Garfinkel 1967; Heritage 1984), deal with the total institution's characteristic combination of isolation and intimacy.

\section{Method}

This article is based on an interactionist perspective on ethnographic data gathered during a threeyear study of interpersonal conflicts in a Swedish youth care institution (Wästerfors 2009a; 2009b; 2011), as well as similar data from an ongoing study of school work in a set of institutions within the same national network. Public youth care in Sweden consists of around 30 so-called "special, approved homes," spread out in the country and harboring youth "with grave psycho-social problems" and cared for under the Care of Young Persons Act (in Swedish $L V U$ ). It also provides 
treatment for youth who have committed serious crimes, sentenced to "secure institutional treatment" within these special, approved homes instead of prison. As this study primarily draws on instances and tendencies that are relevant for the study of social ties, I do not go into detail on my fieldwork more generally (for those details, see Wästerfors 2009a; 2011), but I will nonetheless explain some of the methodological circumstances that made me pay attention to and document social ties in order to start analyzing them, although later on and without planning to do so.

One such circumstance was my recurrent visits at Silverbäcken, the first institution studied (Wästerfors 2009a; 2011), and its "tight" and still somewhat remote atmosphere among the youth (called "pupils"). To reach Silverbäcken I had to go by car from a sizeable urban area and into the countryside, and even there the institution was cut off from its surroundings by its distance from farms and houses. But, I soon learned that I could spot and greet some of the pupils in central neighborhoods in the urban area I just left, when they had their home visits over weekends or vacations. Even though my fieldwork took place in a rural "there," in what seemed to be a social enclave for rehabilitation, field members were situated in urban areas as well, my private "here." At the time, my fieldwork was single-sited, but its members' lives were not.

Further, as I followed days at Silverbäcken, participated in lessons, meals, breaks, activities, excursions, talks, and whatever happened (Wästerfors 2011), I quickly found that I had almost no "backstage region" (Goffman 1990b) in relation to the pupils' intense company. I spent my time in sofas and chairs in the combined living and conference room, at the tables in the dining room or at the entrance to the kitchen where the kitchen maid supplied me with the day's gossip, in the yard or garden, in the school building and its small hall and study rooms, et cetera. Apart from a week or two when I was reading electronic casebooks and so used a small office in the staff wing of the main building, the toilets were the only rooms where I could be alone and, if necessary, write some potentially controversial notes. Otherwise, I took notes openly; sometimes the pupils commented jokingly, sometimes they stole or "borrowed" my notebooks and put notes in them (e.g., “A. IS VERY SMART"). I was in the company of pupils, staff, or both all the time. These experiences intensified when my fieldwork continued some years later in a still ongoing project on schoolwork within this network of public youth care institutions, thereby visiting more institutions. When I am in contact with pupils, I have no escape from intense interaction, and when I go to teachers or other staff members, interaction with them is unavoidable. When I go to and from the institutions by car or train, however, it feels like a commute to a remote and isolated place.

For the purpose of generating ethnographic data, these circumstances can be terrific for ethnography as getting into and sustaining relationships, "to grasp the active «doing» of social life" (Emerson, Fretz and Shaw 1995:14). What I want to point out here is how they made me attend to the settings as conditions for intense sociality and isolation. With the help of analogies to Gubrium's (1997) study of a nursing home, I started to distinguish this quite diffuse or blunt pair of phe- nomena (intimacy-and-isolation) in terms of social ties. I started to note the discrepancy between "getting out" of cities and into quiet and pastoral landscapes, where most of these institutions are placed, and "getting into" inescapable interaction with staff and pupils during a whole day. Writing new ethnographic field notes and re-reading and re-analyzing my previously written ones (Åkerström, Jacobsson and Wästerfors 2004), I tried to get a sense of how field members act under such conditions and - in an ethnomethodological sense (Garfinkel 1967; Heritage 1984) - simultaneously accomplish them.

I attained more material as I came to spend some nights in a youth care institution situated in a region where it was hard to find another place to sleep. First, I borrowed a small cottage just outside the rurally situated and fenced institution, intended for visiting relatives, and then I used a small room for staff working over night. Although I enjoyed the bustling company with pupils and staff during the day, I felt terribly alone at night. One evening, I went out to run in the forests, another evening I joined the pupils' snacking and watching TV in the ward upstairs (even though I was supposed to be "free"); both activities definitely softened my slightly depressing feelings of being disconnected (see Conrad [1997] for interpretations on boredom in terms of disconnection). Methodologically this sensitized my research to conditions of isolation and intimacy, to develop a certain perspective "in conjunction with those in the setting" (Emerson et al. 1995:3). Later on I also used photos, some of which will be shown in this article, since I found it difficult to communicate the aura in and around these "homes" merely with words.
"Cutting off" and "Getting together": Conditions for Social Ties

Gubrium's (1997) findings on social ties in and around an American nursing home in the 1970s have parallels in my data from Swedish youth care institutions forty years later. Gubrium reported on the elderly who missed people, things, and places; they could speak about the institution as their final home, complain about the institutional and not home-like environment, argue that they "deserve better than this," and convey a feeling of injustice at having to live in a nursing home. Against this background, it was important for the elderly to sustain those social ties that remained. To visit relatives and friends was a significant act that never took place without announcements and careful preparations. Recurrent visitors to the nursing home similarly contributed to sustaining ties to the outside world. To have a daughter as a regular visitor was very prestigious, for instance, and telephone calls were essential and worth fighting for; a cancelled call could cause intense, upset feelings among the elderly.

In my data, these tendencies look almost the same: pupils display nostalgia about their homes, cherish visitors from the outside, carefully prepare and announce their home visits, and display feelings of injustice and hostility towards the institution and its staff for cutting their original and identificatory ties. A difference is, of course, that society generally pities the elderly, but not necessarily troublesome youth. Indeed, cutting young people's presumably unhealthy connections with friends and relatives back home belongs to established rehabilitative strategies aimed at 
re-enforcing bonds with conventional society (Platt 1977). Since the beginning of the so-called "child-saving movement," male and lower class adolescents have continuously been relocated from their homes and families to special facilities in the countryside with the intention of saving them from "urban corruption" (Platt 1977:65). The contrast, an imagined "rural purity" is not only thought to provide excellent conditions for rigorous rehabilitative work, but also to transform the youth. The ideology is probably comparable to how rural resorts are celebrated for their curative functions (Friberg 2006). The fact that urban areas from the very beginning of Western youth care systems were associated with social problems and criminality, "the city symbolically embodied all the worst features of modern industrial life" (Platt 1977:40), made replacements logical. Urban areas were seen as the main breeding ground of criminals whereas the country life was thought to be healthier for mind and body.
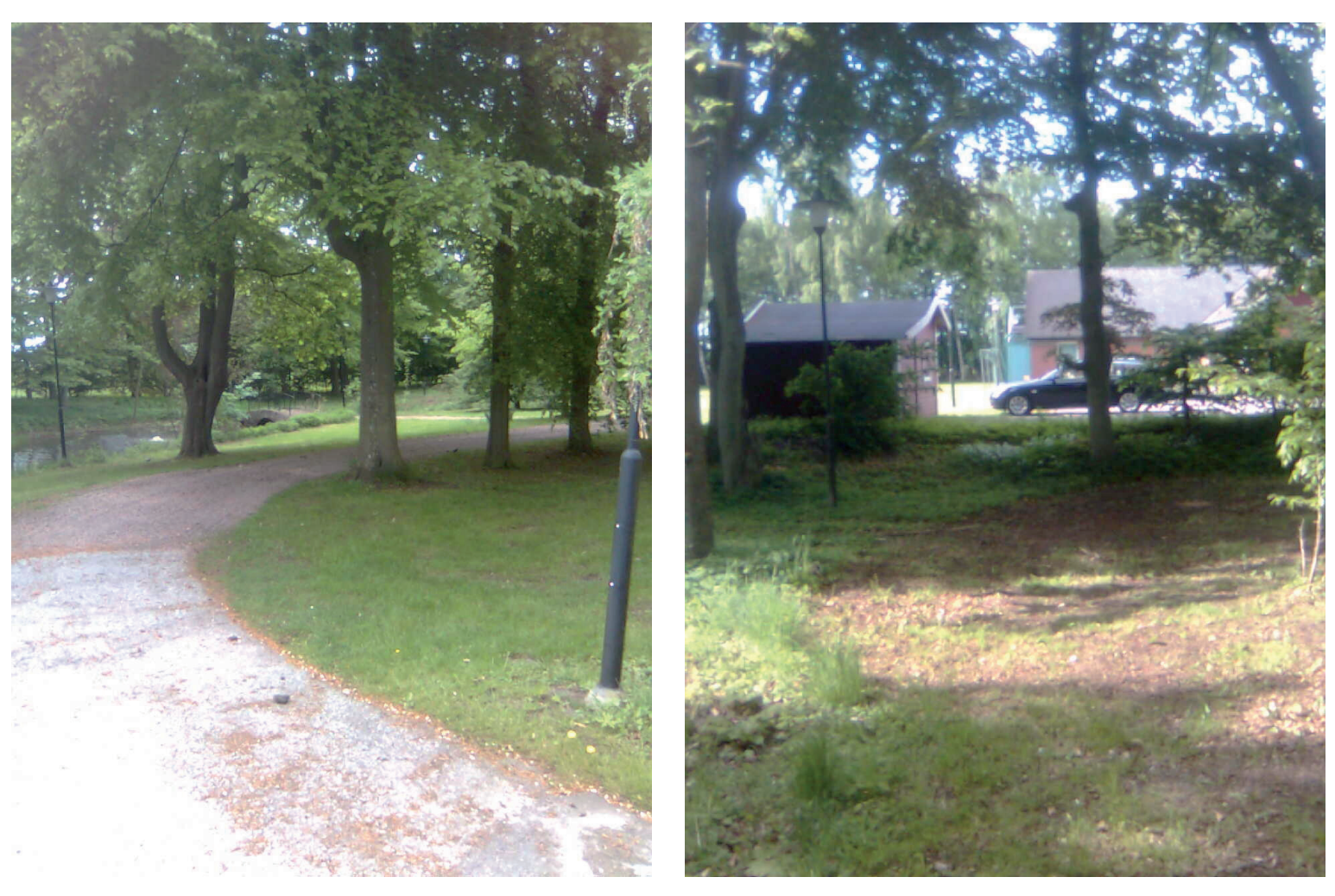

Figure 1. Figure 2 Youth care in stitutions typically communicate a country feeling, as their yystems of cottages are embedded in a "green context." Source: self-elaborated photographs.
The youth care institutions are in this way typically embedded in a green context, far from "the hoods" or betongen in Swedish (literally "the concrete"), which is the expression that the pupils (and sometimes the staff as well) use to refer to their immigrant-dominated city neighborhoods back home. Ironically, though, the physical distance is not always as great

as the symbolic demarcations may imply. As cities grow and as middle class suburbs expand, many of these homes that originally were placed far away are now quite close to villas, roads, schools, gas stations, and shopping malls. Nowadays the rural feeling can be a bit limited, confined to the immediate surroundings.

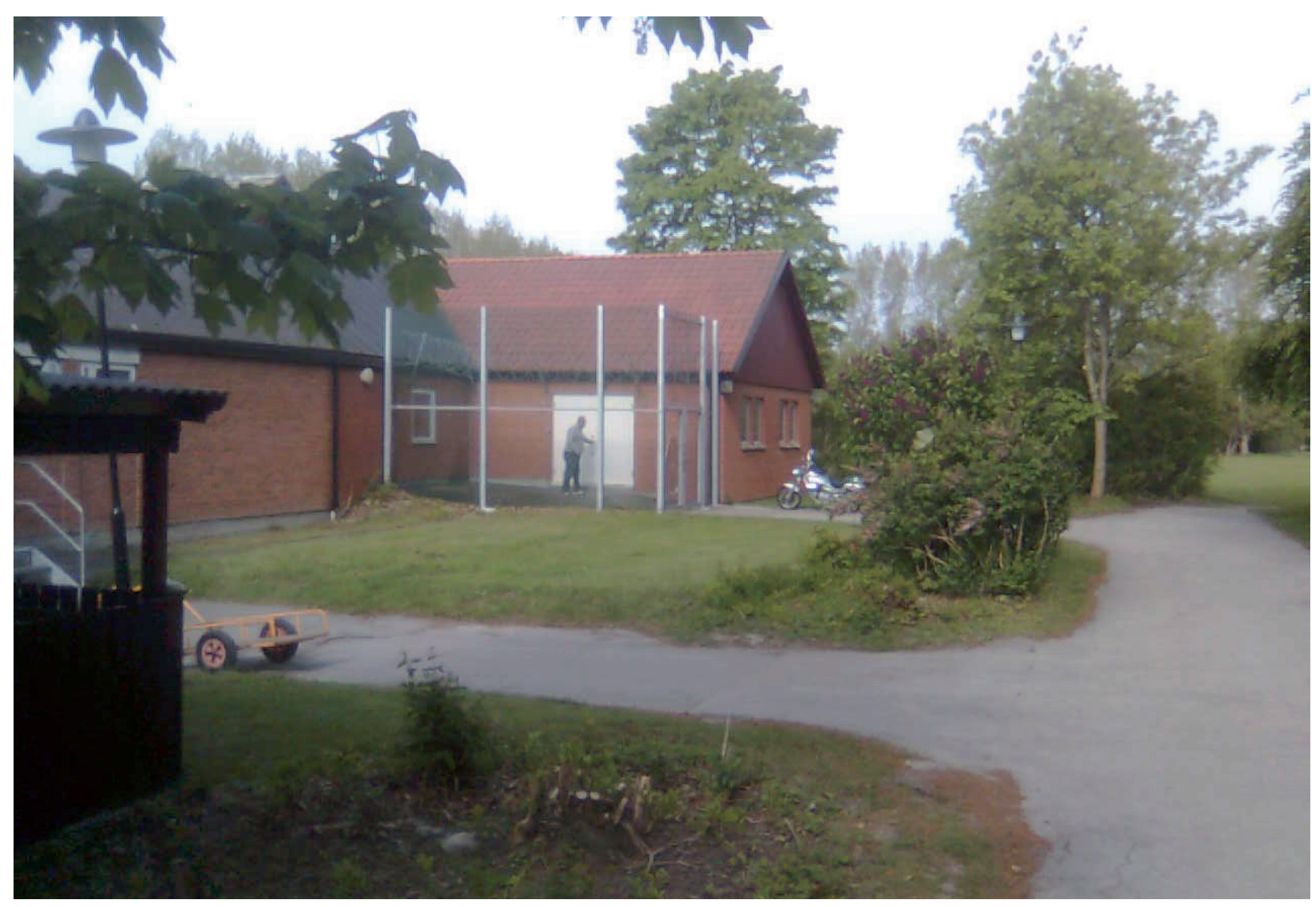

Figure 3. Not until one gets a little closer are the fences and locked doors and windows distinguishable. Source: selfelaborated photograph.

Inside these buildings, one finds what might be called thick interaction regions or settings for intense sociality. School buildings often have small rooms or "work stations" (typically a desk with a computer) large enough for just one or two pupils and a teacher; gyms may even lack windows if they belong to the "secure" wards.
Narrow corridors and living rooms stripped of personal belongings, paintings, and books emphasize the tight atmosphere, as do the small distances between pupils' individual rooms and living rooms and the kitchen on the one hand, and toilets, bath rooms, and laundry rooms on the other. The compulsory leather 
sofa in front of the TV, where pupils and staff are gathering several times a day, also provides conditions for intense interaction. I have a lot of field notes on disputes taking place here (Wästerfors 2009a; 2011), but also on discussions: the jokes, jargons, and commentaries about what is on the TV screen, about staff members coming and going, and so on. I also have notes on situational and institutional responses to disputes or, to borrow Emerson's and Messinger's (1977) terms, the micro-politics of trouble being played out in and around these disputes, as well as notes on physical contacts between pupils and between pupils and staff, and how they are made accountable. In play fights, for instance, it is accountable to touch each other, as opposed to in many other situations where touching can be interpreted as a provocation. Intense interaction is also generated by tight time schedules; school days are filled with short lessons and short breaks, and there are similar schedules for treatment

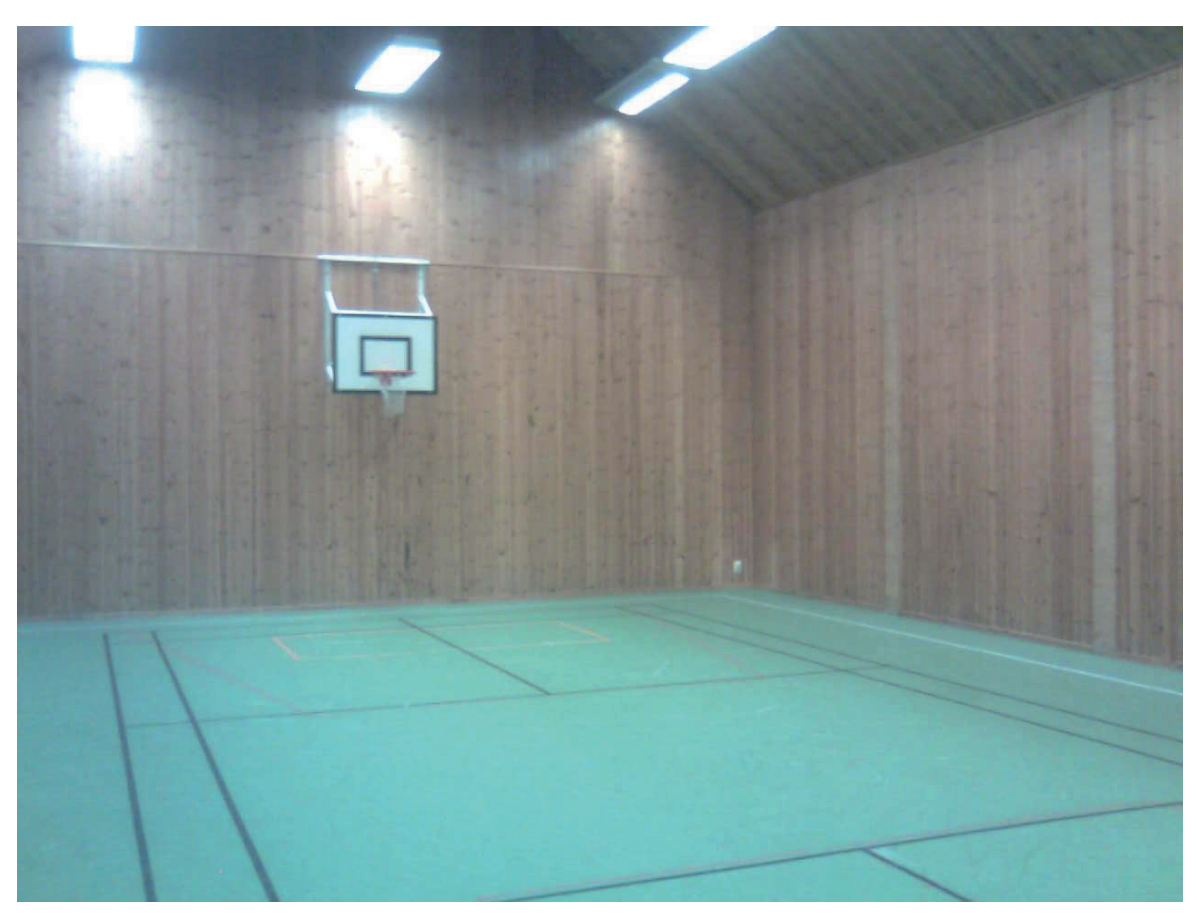

Figure 5. A sports hall without windows since it belongs to a closed secure ward Source: self-elaborated photograph.
At Silverbäcken, unscheduled time was typically filled with unwanted activities from the staff's perspective (Wästerfors 2011). During breaks, or after or during cleaning, pupils could run back and forth in the small corridor outside their rooms, play wrestling with each other or just yelling and irritating staff (Wästerfors 2009a:69). Their internal social ties (e.g., clique formations) were on display in these occasions, for example, when it came to who is to be mocked and how:

[i]t's Wednesday and I stand and talk with Sixten [staff member] about Wednesdays being noisy. "The corridor here is narrow," Sixten says, "everybody runs back and forth when they are supposed to clean" [every Wednesday]. "They have nothing else to do," he says. And this day turns out to be one of those noisy ones: Ron, John, and Magnus [pupils] start fighting, but mostly for fun, it seems. At one occasion, John lifts Magnus and carries him away or almost throws him towards a wastepaper basket in a corner. "No, no, not the basket!" Magnus cries. He does not end up in the basket, John just holds him over it as a joke. Lottie [staff member] is passing and says: "Do you usually do this?" [extract from field notes]

Whereas Magnus' response: “No, no, not the basket!" indicates that this had happened before (and it had), Lottie's question: "Do you usually do this?" indicates surprise and lack of knowledge. Pupils at Silverbäcken used the time during breaks and between activities to try out their strengths against each other and simultaneously try out their social ties: “Can I trust this guy?," "Does he stop playing with me when I ask him to?" - but staff did not always show interest in or awareness of their internal businesses. The fact that social ties were integrated in the quarrel dynamics was shown during the weekly meetings, when pupils complained about others not interrupting play fights despite being explicitly asked to.

Although pupils often find noisy interaction fun or at least captivating, staff are typically very much concerned with securing calm and silence. Staff give so-called hyperactive or stressed pupils tasks or practices that are supposed to pacify them, for instance, cleaning an empty room, away from other pupils, or taking a short break outdoors accompanied by staff only, finishing parts of a puzzle, et cetera. Sometimes staff also offer pacifying objects. Below are some photos of what might be called equipment for stressed individuals: a "stress ball" and other things to make one more relaxed (e.g., toys to practice balance and ball sense). This equipment is given to pupils who are supposed to concentrate on their schoolwork, and avoid being distracted by other pupils' talk, noises, gestures, or mere presence. These relaxing objects are kept in the teacher's office in one of the institution's school buildings and offered to pupils that staff deems to be distressed, worried, restless, and too extroverted in order to make them more loyal to the ongoing concern at issue. 

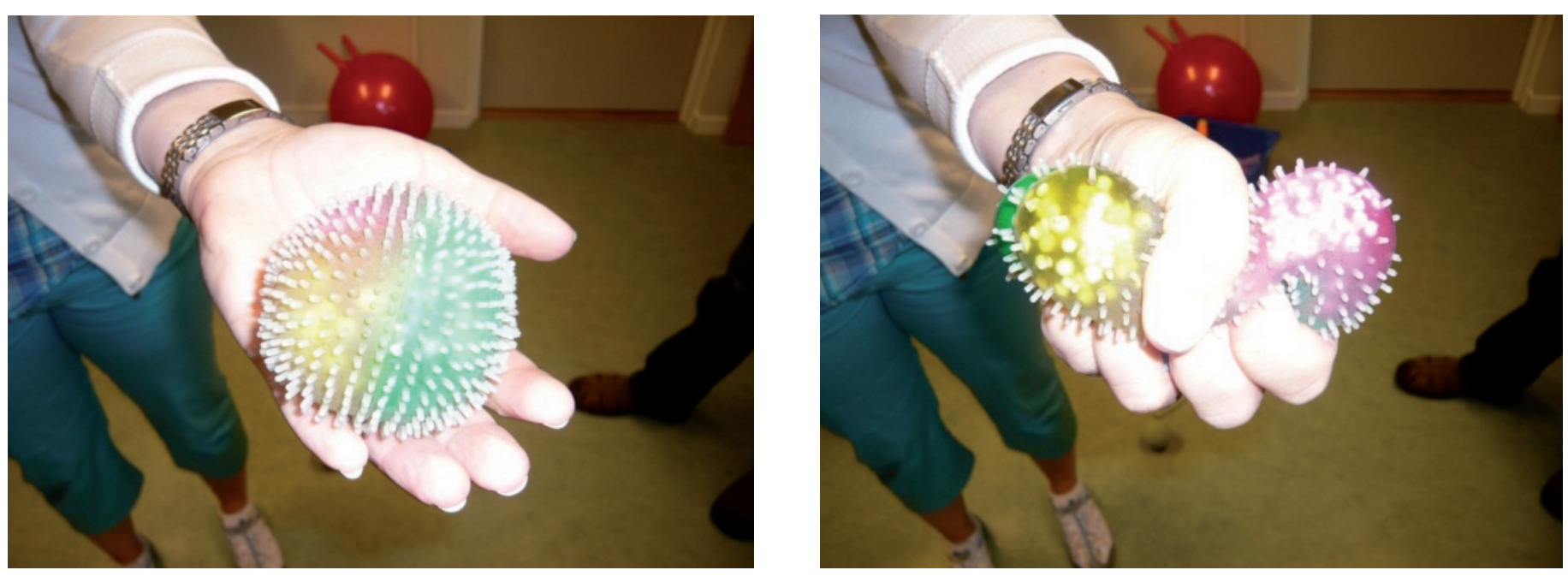

Figure 6. Figure 7. A stress ball, here shown by a teacher, that pupils use in order to calm down and concentrate on schoolwork. Source: self-elaborated photographs.

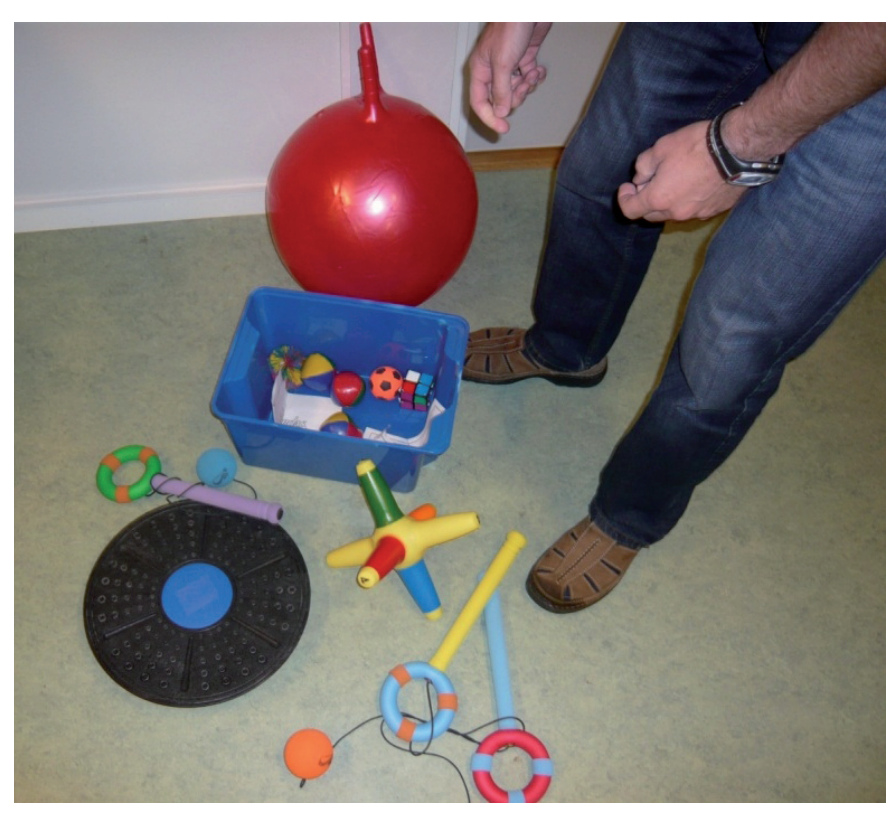

Figure 8. More equipment to make pupils calm and concentrated: toys to practice balance and ball sense. Source: self-elaborated photograph.

Conditions for isolation are intricately combined with conditions for intimacy. Thick interaction regions and a tight and often edgy atmosphere unite a rural and relatively distanced institution, surrounded by symbolic demarcations. Pupils' nostalgic talk about their home neighborhoods and careful planning of their up-coming home visits (I will soon come back to that), their articulations of injustice, and hostility towards any- thing from regulation of cigarette smoking and telephone calls to cleaning and safety routines, are acts that take place in a continuous stream of interaction between institutional members, temporarily cut off from the rest of society. Although prison-like in many respects, youth care institutions are not, as Foucault (1998) presumed regarding prisons, only individualizing and isolating people, rather, they combine temporary replacements with what Sykes (1958) calls "a society of captives" within these institutions, that is to say local communities with intense and occasionally stressful sociality. In the next section, I discuss how to identify more precise methodological entries into this duality and how it is accomplished in everyday life.

\section{Making Social Ties Accountable}

To analyze social ties in total institutions we need to examine not only the institutional prerequisites for the production of isolation and intimacy, but also occasions when this production takes place. The exchange below is quoted from my field notes from the pupil Tim's lesson in a school building within a youth care institution. Tim has just moved from one computer screen to another in order to check some newspapers on the Internet, supervised by the teacher who has given him this task. Then Filip pops by, asking about the laundry:

- Tim, what should I do with your laundry? Filip [a pupil] has just knocked on the door to a schoolroom, opened it, and addressed Tim [another pupil], who sits in front of a computer with his schoolwork.

- Well, put it in the tumble-drier, but don't start it.

- OK.

Tim quickly closes the door. [extract from field notes]

This is an apparently banal episode between one boy sentenced for a narcotics crime and another boy sentenced for murder. At first sight we may say that nothing particular is going on, but after a closer look the episode need not to be viewed as banal.

First, it gives a picture of a "home" in which otherwise separate activities and functions (school work and laundry) are intertwined and connected quickly and in a seemingly self-evident manner, again far from Foucault's (1998) prison in which every individual has a specific place and every place a specific function. Neither the pupils nor the teacher seemed disturbed or amazed over this exchange, despite the fact that it briefly meshes schoolwork with laundry. When Filip is doing his schoolwork he is also supposed to be able to answer questions about his laundry, and when Tim is doing laundry he is perfectly able to pop by Filip's lesson to ask him about it. Second, the episode also manifests a specific social tie between Tim and Filip, comparable to what Gubrium (1997) calls supporters, which also is evident in other instances of my data. As in this example, Tim and Filip sometimes collaborated around everyday tasks, and could count on each other in that sense (even though they did not know each other on the outside). They were doing this in a discreet and apparently "natural" manner that I recognized from other pupils' equally supportive relations in other wards and institutions.

A way to explain the everyday creation of social ties in this setting can be found in the interconnection between these two points. If Tim's and Filip's social tie is seen as not only a background to the current sequence of events or as a social fact "already-there-only-to-be-displayed," but rather as a social tie done and managed here and now in a "seen, but unnoticed" (Heritage 1984:181) fashion, we may say that Tim and Filip make their tie into a "feature of ordinary social interactions and institutional workings" (Heritage 1984:181). They do so by employing institutional circumstances: the laundry, the schoolwork, the fact that they occur simultaneously, and the fact that Tim's laundry must be moved in order to make space for Filip's. These circumstances make their supporting cooperation accountable - visible and reportable, concrete and rational - in the eyes of others as well as themselves.

In this setting, there is nothing strange about Tim answering Filip about laundry during 
a lesson, and similarly nothing strange about Filip interrupting Tim and his lesson with questions about laundry. What is important to keep in mind, though, is that this "naturalness" is not simply there, but accomplished by competent actors who draw on and reproduce their setting's features in terms of a conventionally unnoticed web of everyday accountability (Heritage 1984). Filip does not introduce or explicitly frame his question in any particular way; he just opens a door and says, "Tim, what should I do with your laundry?" as if this act would be perfectly normal. The very self-evident way through which this is done, together with the very setting in which it is done, also makes it so.

Because everyday life in youth care institutions is filled with practical errands and tasks intertwined, there are plenty of opportunities for pupils to create ties in similarly accountable ways. In the above excerpt, Tim and Filip do not simply manifest their social tie, they "do" and "rehearse" this tie by employing youth care circumstances to make it accountable. Conversely, the very "intertwinedness" and intensiveness of institutional life are accomplished through the everyday production and management of social ties.

Interestingly, the institutions' provision of isolation or disconnection can be used and accomplished in similar ways. Consider the following field note, taken during a break and "snack time" between lessons in another youth care institution.
Clemens [a teacher] talks with the boys about "why you're here;" "you're forced to be here, that's how it is," he says, but it is "important to do something with your time." This is referring to a previous fight between a teacher and the boys before the break, presumably intended to motivate them to study instead of fight. Michael and Rick [pupils] complain: "You weren't growing up in the «hoods» [betongen]," Michael says. "No, exactly," Rick says, and goes on: "You don't know what it is about" and looks down at the table. "Even if you behave, «soc» [the social service bureaucrats] is all over you." Then he tells us about how he once got a thousand Swedish crowns [about 100 Euros] from his sister and then got checked by the police in the street and became suspected for things, just because he was carrying this money around.

"If you had a thousand crowns [carried around] they wouldn't have been checking you!" he says to Clemens. Rick says that "Aina is getting at you" - "aina" is [originally Turkish] slang for the police, used in immigrant-dominated suburbs. Michael responds that "«Soc» never has time for you, man" [to help], and Rick says, "«Soc» just gives you another three months [at a special approved home]."

Clemens is listening to all this and then says a phrase I've heard before: "We cannot understand how it is [in the «hoods»], but we can try to understand." He praises Rick for being so interested in schoolwork after all [as he proved to be before, too], that he asks for new things to do in school, and so on. Then he wants to end the break: “Now it's half-past [ten], we have to get going." [It's actually a little later than that.] Clemens finishes the break and says to Michael: “You're having religion now, right?" Everybody returns to rooms and workstations. [extracts from field notes]
Again, it would be easy to suggest that the social gap between staff and pupils displayed in this instance (the pupils coming from the "hoods" [betongen], the staff that openly says they cannot understand the fact that pupils are "forced to be here," et cetera) is merely "out there," as a solid and objective background for Clemens and the pupils to respond and adapt to. But, if we turn our interest to how this distance or disconnection is invoked and drawn upon in interaction, we may - to borrow Heritage's (1984:196) words - start to gain some insight into what "objectivity and facticity consists of," that is to say, how distance and disconnection are made into and managed as unquestionable matters of fact in distinct situations. It is true that staff is locally recruited, and since the institution is situated in an idyllic landscape far from the "hoods" where the pupils are recruited, staff and pupils make up two disparate social categories with different styles, dialects, and backgrounds. It is equally true that the pupils are sentenced or in other ways forced to spend time within the institution whereas staff members are free to leave at any time. However, it is not predetermined that circumstances like these must have significance for all daily interactions between institutional actors, or how they may gain such significance. Therefore, we need to start analyzing how actors invoke and thereby reproduce them in mundane processes.

In the example above, the pupils' rejoinders "you weren't growing up in the «hoods»" and "you don't know what it is about" point out a social cleavage between pupils ("we") and staff ("you"). The staff member's utterance "we cannot understand how it is..." confirms this cleavage whereas the continuation, "...but we can try to understand" tries to bridge it. This local and recurrent staff phrase thereby unites isolation with intimacy: despite the fact that pupils are detached from their "hoods" and that staff cannot understand their original context and background, staff use "but we can try to understand" as a motivating mantra to reach the pupils. Clemens's reminders of schoolwork and his praise of Rick's interest in school serve as a motivation for "back to business" (invoking a local going concern, cf. Wästerfors 2011) and as a soft rebuff of the pupils' attitude.

Rick's and Michael's stories about "soc" (the social service bureaucrats) and "aina" (the police), on the other hand, indicate "sad tales" that account for troublesome or untoward behavior (Scott and Lyman 1968). By invoking these stories, Rick and Michael seem to be saying that (1) there are undeniable and objective reasons for their behavior (both within and outside this institution), and (2) staff cannot fully understand these reasons since pupils belong to a context that staff members know nothing about (betongen). Rick's and Michael's sad tales are quite ingeniously crafted: simultaneously, they are made utterly significant for and inaccessible to staff.

Along these lines, we can analyze how isolation or disconnection in residential youth care can be used and created in various ways. As the difference between "here" and "there" is turned into an interactional resource, overlapping the overall difference between the ru- 
ral institution and the inmates' urban home neighborhoods, differences within the institution are also reproduced, namely the problematically bridged cleavage between staff and pupils. Sad tales from the "hoods" not only tie pupils closer to each other (making up a "we"), they also achieve their isolation within institutional youth care.

A concluding example may help to distinguish how social ties to the outside can be achieved and employed on the inside:

[a]t the end of a lesson, Nora [a teacher] and Isak [a pupil] start talking about Isak's upcoming home visit. It is Friday and Isak is going back home for the first time in weeks; he's "so excited," Nora says repeatedly, and Isak agrees. He starts talking about what he is going to do: they will have tacos at home, and then Isak must take a stroll in the neighborhood. "I will just stand there and breathe," he says, and he shows this by standing in the classroom, closing his eyes and breathing theatrically [and a bit jokingly], as if enjoying the longed-for air of his streets. He does this several times, and talks more about what he misses from home and how he will try to figure out "who's still there and who's not," referring to his friends and what they are up to now. He sounds like he is hoping to get a sense of this just by walking around in his neighborhood and talking with friends and acquaintances [many do not know that he is in juvenile care, he says]. Nora and I keep asking what he is expecting of this visit and we all enjoy the talk. Before, during the lesson on mathematics, Isak had a hard time concentrating, saying that he was "confused" and "wound-up" because of this home visit. Later on he tells his friends in the ward the same thing. [extract from field notes]
To talk up home visits is an interaction ritual (cf. Collins [2004] on, for instance, tobacco rituals) in youth care settings. Similar to Gubrium's (1997) observations among the elderly in a nursing home, a home visit from residential youth care is almost never carried out silently and without announced preparations and expectations. Even though there are cases where the pupil feels uneasy about going home over the weekend (because of family situations or relations), it is no exaggeration to argue that home visits are mostly articulated in a positive fashion. In this example, it is noteworthy that Nora, a teacher, describes Isak's excitement openly, to me and to Isak at the same time, and that his excitement thereby turns into a seemingly objective feeling, accounting for his lack of interest in school.

Thus, Nora and Isak collaboratively boost Isak's home visit and make it into a natural reason for his behavior. His home visit, in turn, signifies his social ties to people back home, on the outside, whereas his storytelling and bodily performance here and now ("closing his eyes and breathing theatrically," "we all enjoy the talk") signify his social ties on the inside. By first telling Nora and me and then his friends in the ward, he uses his home visit, apparently about sustaining old social ties, to sustain his ties to staff and fellow inmates. It later turned out that Isak's home visit lasted only two hours, which further underlines its limited practical significance and its huge symbolic one.

Isak's social ties to both the outside and the inside are made accountable with the help of institutional circumstances. It seems to be an apparent fact that the institution has cut Isak's ties to friends and acquaintances in his original neighborhood, and this fact is employed and rehearsed in his narrated excitement. It would not have made sense to "just stand there and breathe" or try to temporarily repair one's weakened relations by a short home visit had it not been for the isolation that the institution creates. It is also held as an apparent fact that Isak has established new social ties inside the institution, a fact that Isak draws on and reproduces by telling in a personal and quite warm tone about his very much longed for home visit. Consequently, the intense company within the institution this Friday provides Isak with resources for his home visit ritual. Isak, Nora, and other institutional members (including me) make both isolation and intimacy into features of ordinary interactions and institutional workings.

\section{Conclusion}

Using ethnographic data from studies of residential youth care in Sweden, I have identified and discussed two aspects to consider when analyzing social ties in total institutions: (1) conditions for the creation of isolation and intimacy, and (2) their everyday accomplishment by institutional members. Inspired by Gubrium's (1997) analysis of social ties in a nursing home, as well as my own field work experiences in previous and ongoing research projects, I have tried to distinguish not only prerequisites for cutting off and establishing social ties in youth care settings, but also what to look for when analyzing members' methods to make ties accountable - observable and reportable.

The placement of troublesome urban youth in rural areas - from the "hoods" to pastoral landscapes and green surroundings - is apparent, as is the local recruitment of staff and the inherent gap between pupils and staff. Equally apparent are regions for intense sociality inside the institutions' cottages or wards, staff's use of pacifying objects and pupils' use of arenas for the display of social cliques and supporting relations. What is harder to observe is the much more subtle "seen, but unnoticed" (Heritage 1984:181) ways through which institutional members invoke and draw on these and other institutional circumstances to make their social ties seem natural, objective, and unquestionable. We need to study not only institutional conditions for social ties, but also institutional members' use of phrases and stories, their ways of addressing each other and embedding social ties into everyday errands and the other way around, their "theatrical" performances, and their openly recounted feelings. If not analytically treated as "judgmental dopes" (Garfinkel 1967), but as competent and reflexive actors, engaged in projects in their own right, inmates in total institutions can be pictured in and through occasions when they mobilize the institutions' special provision of intimacy and isolation to make their everyday achievement of social ties accountable.

Such an approach offers a less normative stance than research on "peer influence" (Andreassen 2003:137-142; Dodge et al. 2006). Instead of 
merely aiming at minimizing "bad influence," an interest in social ties leads us to investigate the organization and maintenance of social relations in these settings more generally, no matter how they are valued by others. Further, this approach can be fruitful for elaborating transferable sociological perspectives on life in total institutions, especially on how inmates manage and reproduce these institutions' characteristic social conditions, their conditions-at-work. Since institutional features are found and made in everyday occasions, it is not simply a matter of analytically "zooming in" from a bird's eye view of institutions and their overall arrangements to a microscopic view of members' daily interactions, as if the

\section{References}

Åkerström, Malin, Katarina Jacobsson and David Wästerfors. 2004. "Reanalysis of previously collected material." Pp. 344-357 in Qualitative Research Practice, edited by C. Seale, G. Gobo, J. Gubrium, D. Silverman. London, Thousand Oaks, New Delhi: Sage.

Andreassen, Tore. 2003. Institutionsbehandling av ungdomar. Vad säger forskningen? Stockholm: Gothia.

Bondeson, Ulla U. 1974. Fången i fångsamhället. Socialisationsprocesser vid ungdomsvårdsskola, ungdomsfängelse, fängelse och internering. Malmo: Norstedts.

Christie, Nils. 2004. A Suitable Amount of Crime. London: Taylor \& Francis.

Collins, Randall. 2004. Interaction Ritual Chains. New Jersey: The University Press Group. former showed the background and the latter the foreground. Rather, it is a matter of becoming familiar with members' own ways of managing and transcending this sociologically assumed background-foreground approach in mundane practice.

\section{Acknowledgements}

For valuable help and criticism of this work I would like to thank Malin Åkerström, Goran Basic, Margarethe Kusenbach, Katarina Jacobsson and Bernd Rebstein, as well as the journal's anonymous reviewers.

Conrad, Peter. 1997. “It's Boring: Notes on the Meanings of Boredom in Everyday Life." Qualitative Sociology 20(4):465-475.

Dodge, Kenneth A., Thomas J. Dishion and Jennifer E. Lansford. 2006. Deviant Peer Influences in Programs for Youth. Problems and Solutions. New York: The Guilford Press.

Emerson, Robert M. and Sheldon L. Messinger 1977. "The Micro-Politics of Trouble." Social Problems 25(2):121-134.

Emerson, Robert M., Rachel I. Fretz and Linda L. Shaw. 1995. Writing Ethnographic Fieldnotes. Chicago: University of Chicago Press.

Foucault, Michel. 1998. Övervakning och straff. Fängelsets födelse. Lund: Arkiv.
Friberg, Torbjörn. 2006. Diagnosing burn-out: An Anthropological Study of a Social Concept in Sweden. Lund: Lund University Press.

Garfinkel, Harold. 1967. Studies in Ethnomethodology. Cambridge: Polity Press.

Goffman, Erving. 1990a. Asylums. Essays on the Social Situation of Mental Patients and Other Inmates. New York: Anchor Books.

Goffman, Erving. 1990b. The Presentation of Self in Everyday Life. London: Penguin.

Gubrium, Jaber F. 1997. Living and Dying at Murray Manor. Charlottesville, London: The University Press of Virginia.

Heritage, John. 1984. Garfinkel and ethnomethodology. Englewood Cliffs: Prentice-Hall.

Levin, Claes. 1998. Uppfostringsanstalten. Om tvång i föräldrars ställe. Lund: Arkiv.

Platt, Anthony M. 1977. The Child Savers. The Invention of Delinquency. New Brunswick, NJ: Rutgers University Press.

Polsky, Howard W. 1962. Cottage Six. The Social System of Delinquent Boys in Residential Treatment. New York: Russell Sage Foundation.
Scott, Marvin B. and Stanford M. Lyman. 1968. "Accounts." American Sociological Review 33(1):46-62.

Sutherland, Edward H. and Donald R. Cressey. 1970. Criminology. Philadelphia: J.B. Lippincott.

Sykes, Gresham. 1958. Society of Captives. A Study of a Maximum Security Prison. New Jersey: The University Press Group

Wacquant, Loïc. 2009. Prisons of Poverty. Minneapolis: University of Minnesota Press.

Wästerfors, David. 2009a. Konflikthantering $i$ ungdomsvoird ur ett sociologiskt perspektiv. Stockholm: Forskningsrapport nr 3, Statens institutionsstyrelse.

Wästerfors, David. 2009b. “Trouble-Makers and Interactionism: Reconsidering Quarrels in Institutions for Juvenile Delinquents." Journal of Scandinavian Criminology and Crime Prevention 10(1):18-36.

Wästerfors, David. 2011. “Disputes and Going Concerns in an Institution for 'Troublesome' Boys." Journal of Contemporary Ethnography 40(1):39-70. 